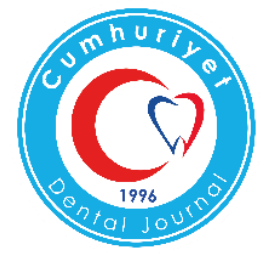

\title{
KNOWLEDGE, ATTITUDE AND PRACTICES OF ORAL AND MAXILLOFACIAL SURGEONS REGARDING BEHAVIOR GUIDANCE TECHNIQUES FOR MANAGING CHILD PATIENTS
}

\author{
Ağız, Diş ve Çene Cerrahisi Uzmanlarının Çocuk Hastalarda Uygulanan Davranış \\ Yönlendirme Tekniklerine Illişkin Bilgi, Tutum ve Uygulamaları
}

\author{
Aydın KESKINRUZGAR ${ }^{1}$, Ayse OZCAN KUCUK ${ }^{2}$, Ebru DELIKAN ${ }^{3}$
}

\section{Makale Kodu/Article Code : : 466826 \\ Makale Gönderilme Tarihi : 03.10 .2018 \\ Kabul Tarihi} \begin{abstract}
Objectives: The aim of this study was to evaluate the knowledge, attitude, and practices of oral and maxillofacial surgeons regarding behavior guidance techniques that reduced fear and anxiety for children.
\end{abstract}

Materials and Methods: In this cross-sectional study, the participants were oral and maxillofacial surgeons who treat pediatric dental patients in the private and public clinics in Turkey. The questionnaires were applied through an electronic form via a website. The results were evaluated using IBM SPSS Statistics 22 for statistical analysis. A p-value of $<0.05$ was accepted as statistically significant.

Results: $60 \%$ of the participants were specialist trainees, $9 \%$ were doctoral students, $16 \%$ were oral and maxillofacial surgeons and $15 \%$ were lecturers in the department of oral and maxillofacial surgery of various universities. $45 \%$ of the participants said they could always take responsibility of working on a pediatric patient, while $33 \%$ of them stated that they frequently treated child patients, and $22 \%$ of them sometimes took this responsibility. $55 \%$ of the participants said they had been trained in behavior guidance techniques for children. The result showed that $93 \%$ of the surgeons used tell-show-do, 69\% used voice control, $27 \%$ used nonverbal communication, $73 \%$ used positive reinforcement, $61 \%$ utilized distraction techniques, $59 \%$ used presence-absence of parents, $15 \%$ used hand-over-mouth, $36 \%$ used sedation, $36 \%$ used restrain/protective stabilization, $46 \%$ used general anesthesia, and $2 \%$ had used hypnosis method.

Conclusion: This study showed that the oral and maxillofacial surgeons working in public and private clinics have a high awareness of behavior guidance techniques while the level of this awareness varies among surgeons according to age, gender, workplace, work experience, and training.

Keywords: Behavioral guidance techniques, awareness, pediatric patients, oral and maxillofacial surgeon

\section{ÖZ}

Amaç: Bu çalışmanın amacı, kamu ve özel kliniklerde çocuk hastalara tedavi hizmeti veren ağız, diş ve çene cerrahlarının korku ve kaygıyı azaltan davranış yönlendirme tekniklerine ilişkin bilgi, tutum ve uygulamalarını değerlendirmektir.

Gereç ve Yöntemler: Bu kesitsel çalışmada, katılımcılar Türkiye'deki özel ve kamu kliniklerinde çocuk hastaları tedavi hizmeti veren ağız ve çene cerrahlarıdır. Anketler bir web sitesi üzerinden elektronik form aracılığıyla uygulandı. Çalışmada elde edilen bulgular IBM SPSS Statistics 22 (IBM SPSS, Türkiye) programı kullanılarak değerlendirildi. Anlamlılık $\mathrm{p}<0,05$ düzeyinde değerlendirildi.

Bulgular: Katılımcıların \%60'1 uzmanlık öğrencisi, \%9'u doktora öğrencisi, \%16'sı ağız diş ve çene cerrahı, \%15'i üniversitede ağız diş ve çene cerrahisi bölümünde öğretim üyesiydi. Hekimlerin \%45'i her zaman çocuk hastada çalışma sorumluluğunu alabildiğini söylerken, \%33'ü sık s1k, \%22'si bu sorumluluğu bazen aldığını belirtti. Katılımcıların \%55'i çocuklarda davranış yönlendirme teknikleri hakkında eğitim aldığını belirtti. Katılımcıların kullandıkları davranış yönlendirme teknikleri sorulduğunda, \%93'ünün anlat-göster-uygula, \%69'unun ses kontrolü, \%27'sinin sözsüz iletişim, \%73'ünün pozitif destekleme, \%61'inin ilgiyi dağıtma, \%59'unun ebeveyn varlığı-yokluğu, \%15'inin ağzın elle örtülmesi, \%36'sının çocuğun sabitlenmesi, \%36'sının sedasyon, \%46'sının genel anestezi ve \%2'sinin hipnoz yöntemini kullandığı tespit edildi.

Sonuç: $\mathrm{Bu}$ çalışmanın sonuçları, çene cerrahlarının davranış yönlendirme teknikleri konusundaki farkındalığının yüksek olduğunu ve bu farkındalığın yaş, cinsiyet, çalışma yeri, çalışma deneyimi ve eğitime göre bireysel farklılık oluşturduğunu göstermektedir.

Anahtar kelimeler: Davranış yönlendirme teknikleri, farkındalık, pediatrik hasta, ağız diş ve çene cerrahı

\footnotetext{
${ }^{1}$ Adiyaman University, Faculty of Dentistry, Department of Oral and Maxillofacial Surgery, Adiyaman, Turkey

${ }^{2}$ Mersin University, Faculty of Dentistry, Department of Oral and Maxillofacial Surgery, Mersin, Turkey

${ }^{3}$ Mersin University, Faculty of Dentistry, Department of Pediatric Dentistry, Mersin, Turkey
} 


\section{INTRODUCTION}

Dental procedures, such as tooth extraction or treatment, cause a great deal of fear and anxiety among the majority of child patients. Especially, painful dental procedures cause anxiety and worsen children's behavior. ${ }^{1}$ For this reason, children who have had previous tooth extraction feel more pain, fear, and discomfort. These emotions can cause serious difficulties during the procedure by resulting in non-collaborative behaviors during subsequent dental appointments. ${ }^{1,2}$

On the other hand, it has been shown that as children become more familiar and experienced with dental procedures, they adapt and cooperate more easily. The experience gained in previous dental appointments helps the child get accustomed to dental procedures and identify the non-threatening aspects of dental appointments. ${ }^{3}$ In addition, in some children, the choice of the dentist's persuasive approach can affect the behavior of the child positively, enabling cooperation between the physician and the child.

Oral and maxillofacial surgeons are expected to manage pediatric surgical procedures effectively with the knowledge and skills they acquire during dental school education. However, ensuring safe and effective treatment during dental procedures often requires changing the behavior of the child. The purpose of guiding behaviors during treatment of children is to provide an environment that will facilitate the child's acceptance of treatment, especially in cases of frightening and anxiety-causing procedures such as tooth extraction. Providing these conditions depends on the practitioner's experience and skills in using appropriate behavior guidance techniques. ${ }^{4,5}$ Behavioral guidance techniques include communication, fear and anxiety relief, providing quality dental care, establishing a reliable relationship between the dentist, the child and the parent, and to encourage the child to positively approach the dental treatment. ${ }^{6}$
The aim of this study was to evaluate the knowledge, attitude, and practices of oral and maxillofacial surgeons regarding behavior guidance techniques that reduced fear and anxiety for children.

\section{MATERIALS AND METHODS}

The study protocol was approved by the Mersin University Non-invasive Clinical Research Ethics Committee (2018/48). This crosssectional study was performed between January 1 and July 1, 2018, and the participants were oral and maxillofacial surgeons who treat pediatric dental patients in the oral and maxillofacial surgery clinics in Turkey. The questionnaires were applied through an electronic form via a website and the participants were informed about the study at the beginning of the survey.

Oral and maxillofacial surgeons working at the universities, Oral and Dental Health Centers (ODHCs), private practices or private clinics providing pediatric treatment services, or specialist or doctoral students studying in this field were included in the study.

Surveys were prepared as electronic forms. In order to prevent non-specialists from participating in the survey, 211 oral and maxillofacial surgeons, who were contacted through e-mail, were asked to fill in the surveys.

The results were evaluated using IBM SPSS Statistics 22 (SPSS IBM, Turkey) for statistical analysis. Chi-square test, Fisher's Exact Chi-square test, Continuity (Yates) correction and Fisher Freeman Halton test were used to compare qualitative data as well as the descriptive statistical methods (frequency). A pvalue of $<0.05$ was accepted as statistically significant.

\section{RESULTS}

100 out of 211 oral and maxillofacial surgeons answered the questionnaire. The participation rate was $48 \% .27 \%$ of the oral and maxillofacial surgeons participating in the survey were 
female and $73 \%$ were male. $60 \%$ of the participants were specialist trainees, $9 \%$ were doctoral students, $16 \%$ were oral and maxillofacial surgeons, and $15 \%$ were lecturers in the department of oral and maxillofacial surgery of various universities. $68 \%$ of the participants were between the ages of 23-30, $25 \%$ between the ages of $31-40$, and $7 \%$ between the ages of $41-50.87 \%$ of the participants had a work experience of $1-5$ years, $8 \%$ had 5-10 years, and 5\% had 10 or more years. $87 \%$ were working in the faculty of dentistry of different universities, $7 \%$ were in private practice or clinics, and $6 \%$ were working in ODHCs (Table 1).

$\underline{\text { Table 1: Demographics distribution of participants }}$

\begin{tabular}{llcc}
\hline \multirow{2}{*}{ Sex } & & $\mathbf{n}$ & $\%$ \\
\hline \multirow{2}{*}{ Title } & Female & 27 & 27 \\
& Male & 73 & 73 \\
\hline & Specialist students at the university & 60 & 60 \\
& Doctoral students at the university & 9 & 9 \\
& Oral and maxillofacial surgeon & 16 & 16 \\
& Lecturer at the university & 15 & 15 \\
\hline \multirow{2}{*}{ Wore } & $20-30$ & 68 & 68 \\
& $31-40$ & 25 & 25 \\
& $41-50$ & 7 & 7 \\
\hline \multirow{2}{*}{ Type of practice } & 1-5 years & 87 & 87 \\
& 5-10 years & 8 & 8 \\
& Private practices or private clinics & 7 & 7 \\
& Oral and Dental Health Centers & 6 & 6 \\
& Faculties of Dentistry & 87 & 87 \\
\hline
\end{tabular}

$45 \%$ of the participants said they could always take responsibility of working on a pediatric patient, while $33 \%$ of them stated that they frequently treated child patients, and $22 \%$ of them sometimes took this responsibility. $55 \%$ of the participants said they had been trained in behavior management techniques for children.

While $79 \%$ of oral and maxillofacial surgeons thought that they needed family permission to conduct behavioral guidance, $25 \%$ of them stated that they always used behavior guidance techniques for child patients.

When we asked about the behavior guidance techniques used by the surgeons, they used; $93 \%$ used tell-show-do, $69 \%$ used voice control, $27 \%$ used nonverbal communication, $73 \%$ used positive reinforcement, $61 \%$ utilized distraction techniques, 59\% used presenceabsence of parents, $15 \%$ used hand-over-mouth, $36 \%$ used sedation and restrain/protective stabilization, $46 \%$ used general anesthesia, and $2 \%$ had used hypnosis method.

98\% of the respondents gave a "no" answer when asked "Are all of the behavior management techniques appropriate for every child?" question. When asked, "Would you prefer not to talk at all if the child is quiet and cooperative during the treatment?" $7 \%$ of the respondents answered "always", 17\% stated “often”, 33\% said "sometimes", $43 \%$ responded "never".

When the participants were asked "Do you allow the child to talk or ask questions during treatment?", 19\% answered "always", 53\% said "often", 27\% stated "sometimes", 1\% responded as "never".

When asked "Do you stop the treatment when the child feels uncomfortable?", $23 \%$ of the respondents answered "always", $41 \%$ responded "often", and 36\% said "sometimes".

When they were asked "Do you prefer to give a gift or a prize if the child behaves in a cooperative manner during treatment?", 5\% answered "always", 27\% "often", 58\% "sometimes", $10 \%$ responded "never" (Table 2). 
Table 2: The distribution of responses to the survey questions

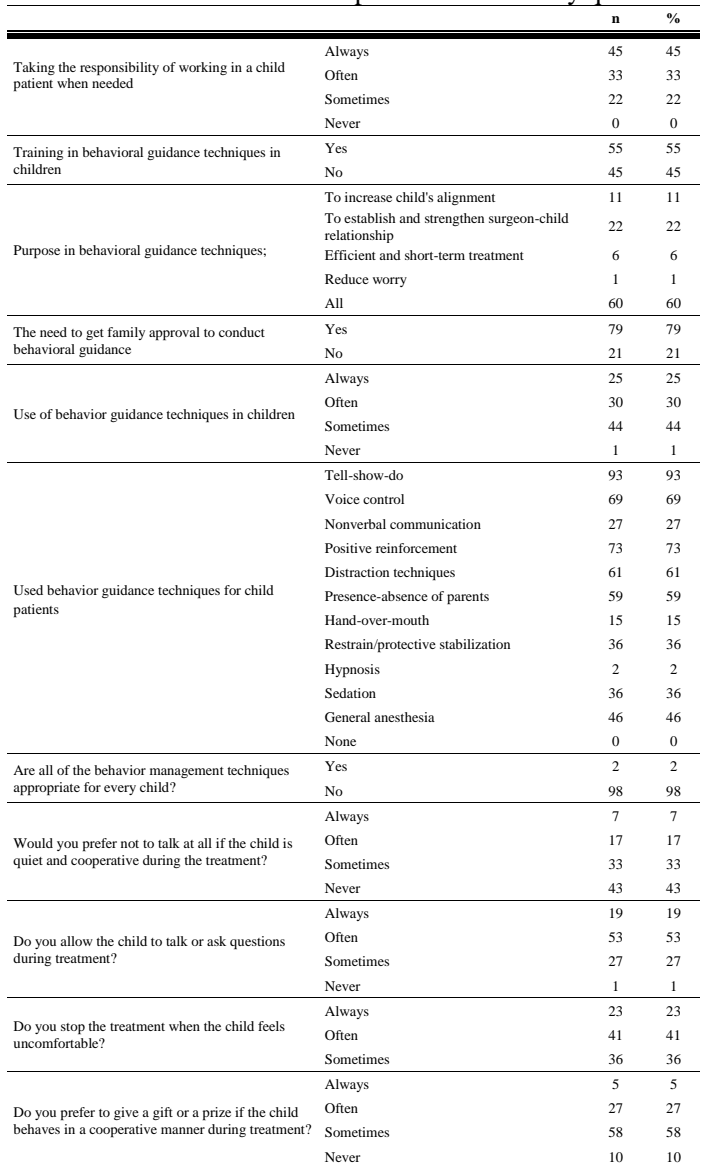

There was no statistically significant difference in the frequency of dentists for taking responsibility of pediatric dental patients with regards to gender $(p>0.05)$. Although more female dentists $(70.4 \%$ of female participants) stated that they received education on behavioral guidance techniques in children compared to male surgeons $(49.3 \%$ of male participants), the difference was not statistically significant $(p>0.05)$. There was no statistically significant difference between male and female participants with respect to the belief that family members should obtain permission from the family to conduct behavioral guidance ( $p>0.05)$. On the other hand, there was a statistically significant difference between the frequency of use of behavior guidance techniques in children with respect to gender $(\mathrm{p}=0.001)$, where the female surgeons were significantly more likely to use behavior guidance techniques $(51.9 \%)$ than males $(15.1 \%)$.
The rate of use of voice control by female physicians (88.9\%) was significantly higher than that of males $(61.6 \%)(\mathrm{p}=0.018)$. The rate of use of parental presence/absence by female surgeons (92.6\%) was also significantly higher than that of males $(46.6 \%)(p=0.000)$. Nevertheless, there was no statistically significant difference in the rates of use of other behavior-orienting techniques between the participants with different genders ( $p>0.05$ ).

There was a statistically significant difference between the frequencies of "not talking at all if the child patient is quiet and cooperative" $(p=0.008)$, where the rate of the male dentists who prefer to not talk often (23.3\%) was significantly higher than that of females $(0 \%)$ (Table 3).

Table 3: Assessment of responses to questionnaires according to

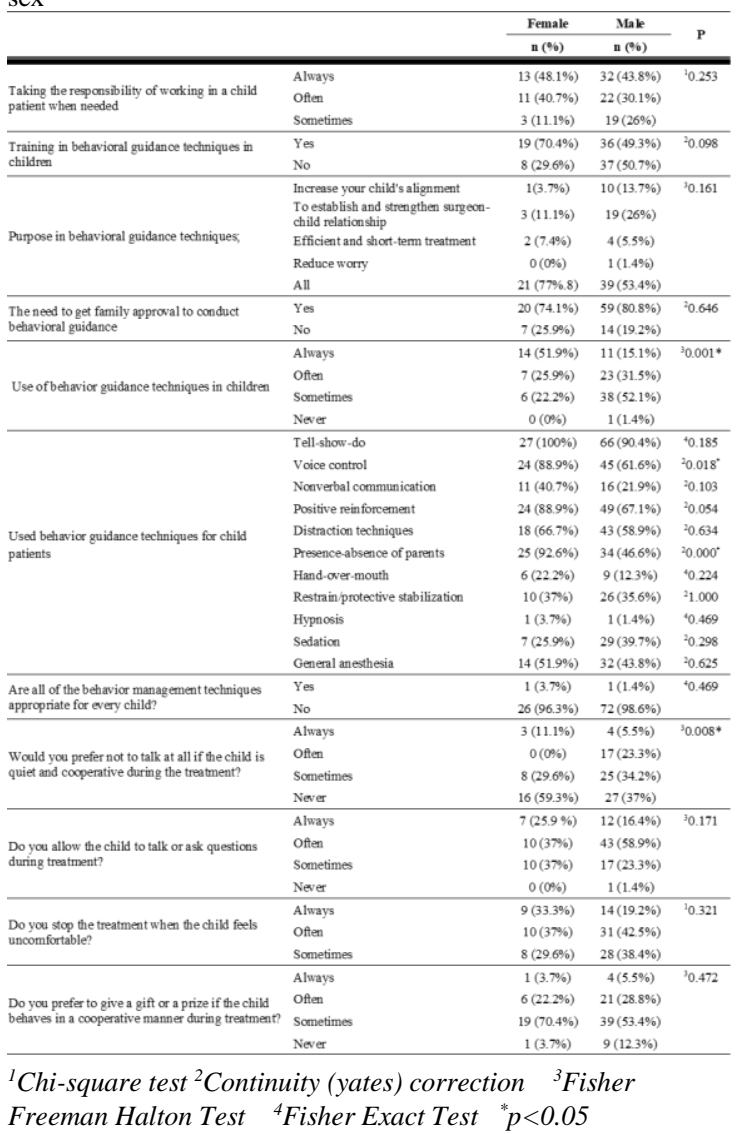

There was a statistically significant difference ( $\mathrm{p}=0.012$ ) between participants from different age groups with respect to the rate of receiving education in behavior guidance techniques for children. $85.7 \%$ of the surgeons between the 
ages of $41-50,60.3 \%$ of the surgeons between the ages of $23-30$, and $32 \%$ of the surgeons between the ages of 31-40 received an education on these techniques. There were also statistically significant differences $(\mathrm{p}=0.000$, $\mathrm{p}=0.042, \mathrm{p}=0.001$ ) in using the voice control, distraction and use of hand over mouth technique with respect to age (Table 4).

Table 4: Assessment of responses to questionnaires according to age

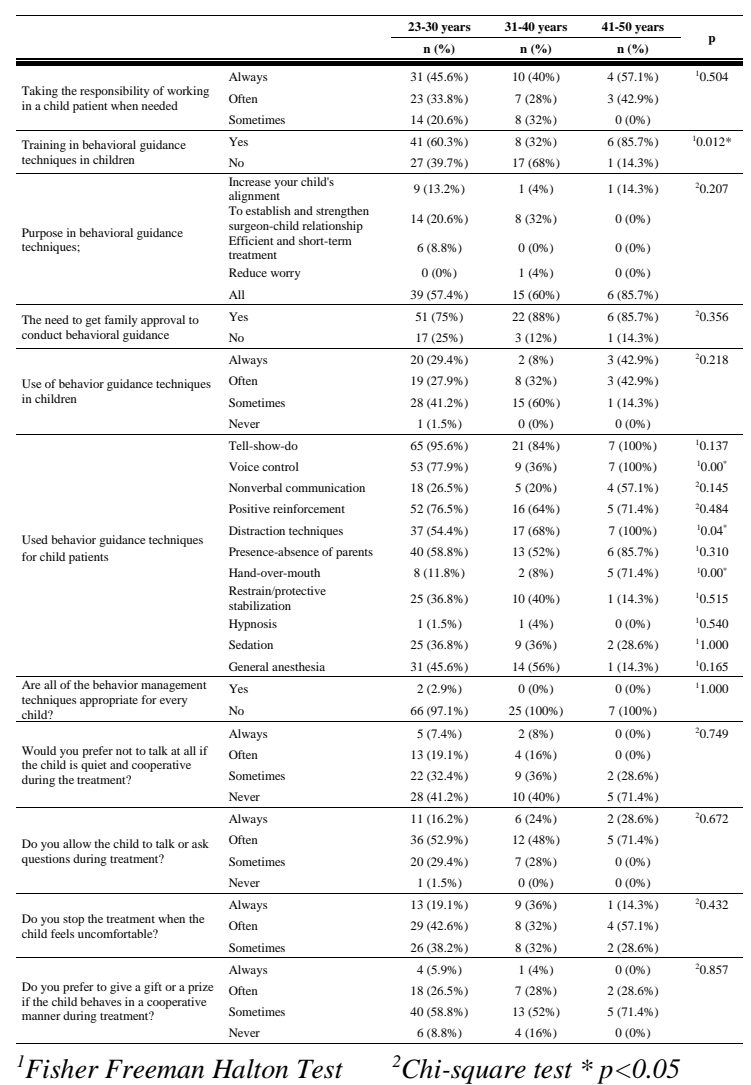

Regarding the frequency of use of behavioral guidance techniques and the rates of use of these techniques in child patients, there was no statistically significant difference between the groups of surgeons with different working experience $(\mathrm{p}>0.05)$ (Table 5).
Table 5: Assessment of responses to questionnaires according to working experience

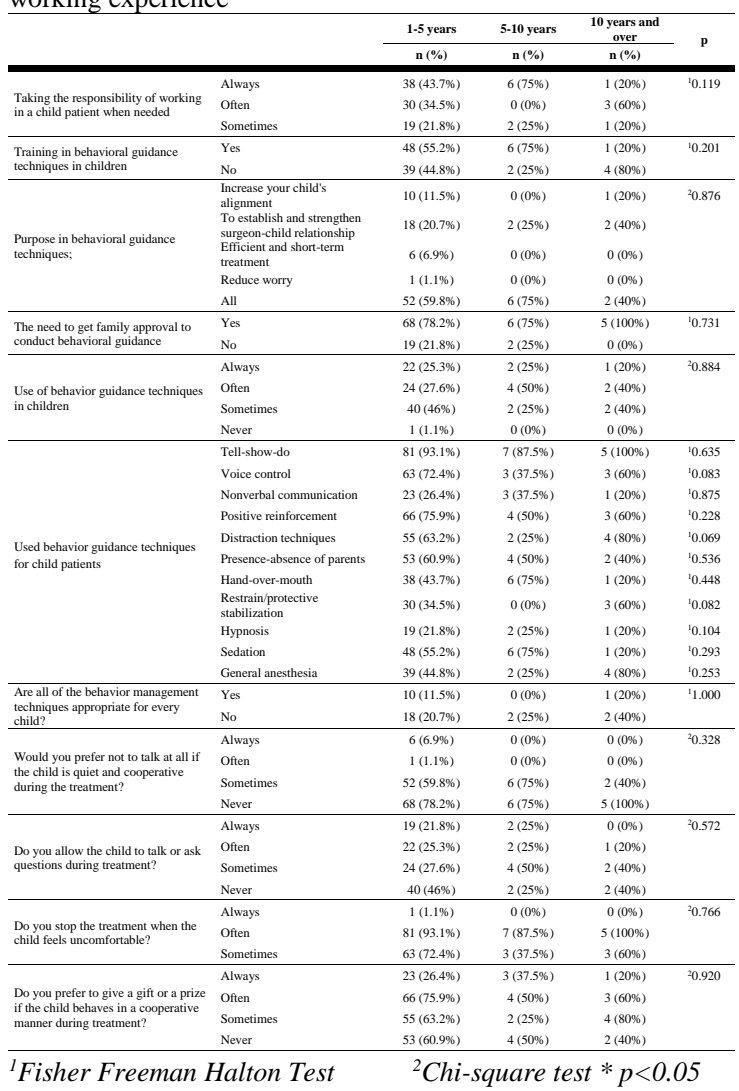

There was a statistically significant difference ( $\mathrm{p}=0.01$ ) between the participants from different institutions with respect to using the behavioral guidance techniques in children. $59.8 \%$ of university-affiliated surgeons and $42.9 \%$ of private practitioners or clinicians had been trained, however, the surgeons working in the ODHCs did not receive training.

There was a statistically significant difference between the frequencies of using tellshow-do technique among the participants who were employed at different institutions $(p=0.005)$. While $96.6 \%$ of university-affiliated surgeons used this technique, $71.4 \%$ of those working in private practice and $66.7 \%$ of those working in ODHCs used this technique.

The frequencies of using the voice control techniques among surgeons employed in different institution types were statistically significantly different $(\mathrm{p}=0.005)$, where $73.6 \%$ of surgeon working in university, $66.7 \%$ of surgeons working in ODHCs, and $14.3 \%$ of the employees in private practice used this technique. 
There was also a statistically significant difference between the frequencies of using the distraction technique between surgeons from different institutions $(\mathrm{p}=0.012) .83 .3 \%$ of surgeons working in ODHC and $63.2 \%$ of surgeon working in university used this technique, while only $14.3 \%$ of those working in private practice utilized this technique.

In terms of the frequency of use of parental presence/absence technique, there was also a statistically significant difference between physicians from different institutions $(\mathrm{p}=0.045)$; While $66.7 \%$ of surgeons working in ODHCs and $62.1 \%$ of university employees were using this technique, only $14.3 \%$ of those working in private practice stated that they use this technique.

There was a statistically significant difference between the frequency of using the sedation technique by surgeons working in different types of institutions ( $\mathrm{p}=0.004)$; where $85.7 \%$ of the employees in the private practice and $34.5 \%$ of the university employees used this technique, but none of the surgeons working in ODHCs used this technique (Table 6).

Table 6: Assessment of responses to questionnaires according to type of practice

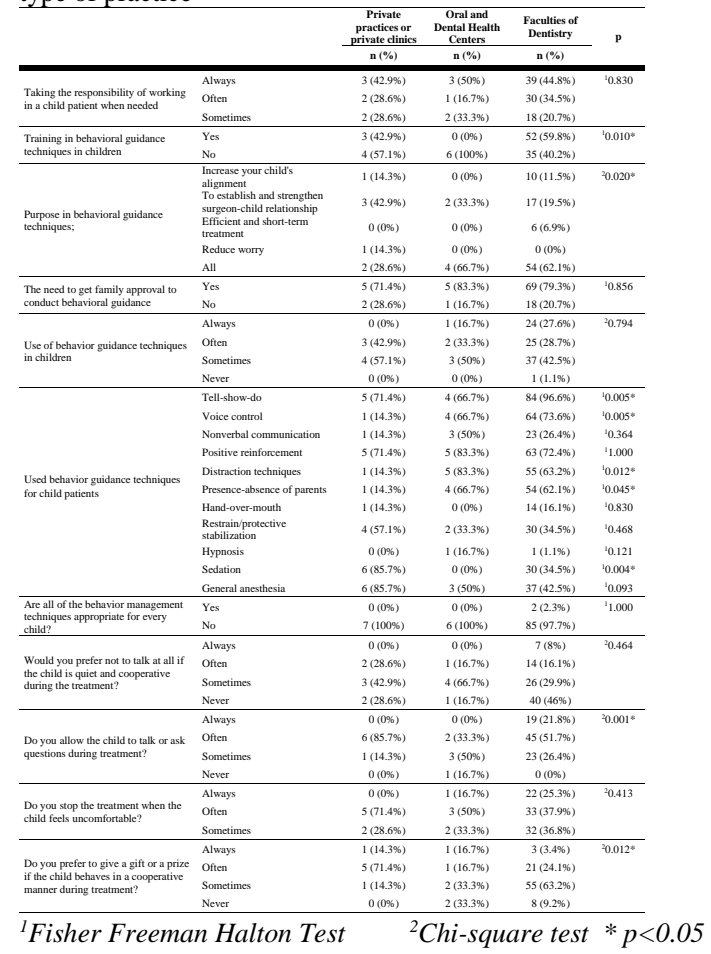

\section{DISCUSSION}

It is quite difficult to examine and treat child patients. For this reason, oral and maxillofacial surgeons may be reluctant to treat or take responsibility for young child patients. A survey conducted in Pakistan showed that $36.5 \%$ of dental surgeons always, $22 \%$ often, $38 \%$ sometimes and $3.5 \%$ never take responsibility for the treatment of pediatric patients (5). Findings from our study showed that $45 \%$ of surgeons always, $33 \%$ often, and $22 \%$ sometimes took this responsibility. We did not observe any surgeon who did not treat pediatric patients. The present study is the first study evaluating the knowledge, attitude, and practices of oral and maxillofacial surgeon regarding behavior guidance techniques in Turkey.

This study shows that the vast majority of the surgeons working in the oral and maxillofacial clinics in Turkey (99\%), and 79\% of all oral and maxillofacial surgeons always use behavior guidance techniques. Similarly, Ajlouni et $a .^{7}$ have reported that $85 \%$ of Jordanian pediatric dentists always use the behavior guidance techniques.

Use of the behavior guidance techniques is an integral part of the pediatric dentistry practice. ${ }^{8}$ In our study, $25 \%$ of the oral and maxillofacial surgeon working in maxillofacial surgery clinics used behavioral guidance techniques in children at all times and the most frequently used behavioral guidance techniques were tell-show-do (93\%), positive support (73\%), voice control (69\%), distraction (61\%) and parental presence/absence (59\%). McKnight-Han et al. ${ }^{9}$ showed that $96 \%$ of general dentists used tell-show-do and $88 \%$ used voice control, while $100 \%$ of pediatric dentists used tell-show-do and 98\% of them used voice control. Sharath et al. ${ }^{10}$ and Grewal et al. ${ }^{11}$ reported that the most commonly used behavioral guidance technique in India is tellshow-do. In the study conducted by Wali and colleagues, ${ }^{4}$ the most popular techniques that 
dental surgeons used to manage children were stated to be distraction (33.5\%), voice control (30.5\%), and tell-show-do (29.5\%). In the same study, $34 \%$ of the dental surgeons reported that they allowed the parents of the pediatric patients in their clinic during treatment. ${ }^{4}$ In one study conducted in Israel, Peretz et al. ${ }^{12}$ reported that dentists use tell-show-do and material reinforcement techniques more often than other behavior guidance techniques. Hypnosis $(6 \%)$ was reported to be the least used method in the same study. ${ }^{12}$ Hypnosis (2\%) was also found to be the least used method in our study.

In the present study, there was a statistically significant difference between surgeons from different age groups with respect to control by voice, distracting, and using hand covering technique. In previously published studies, no significant difference was found between different age groups regarding any of the behavioral guidance techniques. ${ }^{13,14}$

We also determined that the pharmacological methods were also preferred by surgeons as behavior guidance techniques and that $36 \%$ of the surgeons used sedation and $46 \%$ used general anesthesia. There was no significant difference in sedation or general anesthesia use between male and female surgeons. Peretz et al. ${ }^{12}$ observed that the use of general anesthesia was significantly more prevalent among male dentists than among females, and there was no significant difference between male and female dentists in terms of sedation use.

Wright et al. ${ }^{15}$ reported that young dentists tend to use behavior guidance techniques more often than older dentists. In our study, it was observed that pediatric patients were treated mostly by young and university-affiliated surgeons (ages 23-30), and the behavioral methods were also used more often by younger (23-30 years), less experienced and universityaffiliated surgeons. The use of behavioral guidance techniques by younger and less experienced surgeons can be explained by the positive changes in the curriculum in the faculties of dentistry that has taken place over time and the availability of more course opportunities. The more frequent use of behavior guidance techniques by universityaffiliated surgeons is considered to be due to the fact that the vast majority of the participants were working at universities and that the pediatric patients are frequently referred to university hospitals due to the presence of pediatric dental clinics.

In line with the previous studies, ${ }^{15,16}$ we found that the rate of behavior guidance technique use among female surgeons was statistically significantly higher than males. On the contrary to our work, Kawia et al. ${ }^{5}$ reported that male surgeons used these techniques more than females.

\section{CONCLUSION}

In general, the results of this study show that the oral and maxillofacial surgeons working in public and private clinics have a high awareness of behavior guidance techniques while the level of this awareness varies among surgeons according to age, gender, workplace, work experience, and training. Training programs should be planned for the oral and maxillofacial surgeons to improve their knowledge and skills in providing treatment for children.

\section{Conflict of Interests}

The authors declare that there are no conflicts of interest regarding the publication of this paper.

\section{REFERENCES}

1. Cademartori MG, Martins $P$, Romano AR, Goettems ML. Behavioral changes during dental appointments in children having tooth extractions. J Indian Soc Pedod Prev Dent 2017;35:223-228.

2. Baier K, Milgrom P, Russell S, Mancl L, Yoshida T. Children's fear and behavior in private pediatric dentistry practices. Pediatr Dent 2004;26:316-321. 
3. Howitt JW, Stricker G. Sequential changes in response to dental procedures. J Dent Res 1970;49(5):1074-1077.

4. Wali A, Siddiqui TM, Khan R, Batool K. Knowledge, Attitude, and Practices of Dental Surgeons in managing Child Patients. Int J Clin Pediatr Dent 2016;9:372-378.

5. Kawia HM, Mbawalla HS, Kahabuka FK. Application of Behavior Management Techniques for Paediatric Dental Patients by Tanzanian Dental Practitioners. Open Dent J 2015;9:455-461.

6. Boka V, Arapostathis K, Vretos N, Kotsanos N. Parental acceptance of Behaviormanagement techniques used in pediatric dentistry and its relation to parental dental anxiety and experience. Eur Arch Paediatr Dent 2014;15:333-339.

7. Ajlouni O, Al-Moherat F, Habahbeh R, Nsour H, Tbeshat J. Behavior management techniques among Jordanian pediatric dentists. J Royal Med Services 2010;17:62-66.

8. Carr KR, Wilson S, Nimer S, Thornton JB Jr. Behavior management techniques among pediatric dentists practicing in the southeastern United States. Pediatr Dent 1999;21:347-353.

9. McKnight-Hanes C, Myers DR, Dushku JC, Davis HC. The use of behavior management techniques by dentists across practitioner type, age, and geographic region. Pediatr Dent 1993:15:267-271.

10. Sharath A, Rekka P, Muthu MS, Rathna Prabhu V, Sivakumar N. Children's behavior pattern and behavior management techniques used in a structured postgraduate dental program. J Indian Soc Pedod Prev Dent 2009;27: 22-26.

11. Grewal N. Implementation of behavior management techniques: how well accepted they are today. J Indian Soc Pedod Prev Dent 2003;21:70-74.

12. Peretz B, Glaicher H, Ram D. Childmanagement techniques. Are there differences in the way female and male pediatric dentists in Israel practice? Braz Dent J 2003;14:82-86.

13. Lawrence SM, Dennis MS, McTigue, Wilson S, Waggoner WF, Fields HW Jr. Parental attitudes toward behavior management techniques used in pediatric dentistry. Pediatr Dent 1991;13:151-155.

14. Daghamin $S$, Balharith $M$, Alhazmi $S$, AlObaidi F, Kakti A. Behavior Management Techniques in Pediatric Dentistry: How Well are they Accepted? Acad J Ped Neonatol 2017;5:555722.

DOI: 10.19080/AJPN.2017.05.555722.

15. Wright FA, Giebartowski JE, McMurray NE. A national survey of dentists' management of children with anxiety or behavior problems. Aust Dent J 1991;36:378-383.

16. Adair $S$, Schafer $T$. Age and gender differences in the use of behavior management techniques by pediatric dentists. Pediatrics 2007;29:403-408.

\section{Corresponding Author}

Ayse OZCAN-KUCUK, DDS, MDS

Mersin University

Faculty of Dentistry

Department of Oral and Maxillofacial Surgery

Mersin, 33343, Turkey

Phone : +903243610037

Fax : : +903243610369

E-mail : ayseozcan89@hotmail.com 